\title{
Evidence for two koi herpesvirus (KHV) genotypes in South Korea
}

\author{
Hyoung Jun Kim¹, Se Ryun Kwon ${ }^{2, *}$ \\ ${ }^{1}$ Animal, Plant and Fisheries Quarantine and Inspection Agency, Jungbu Regional Office, Incheon 400-800, South Korea \\ ${ }^{2}$ Department of Aquatic Life Medical Sciences, Sunmoon University, Asan-si, Chungnam 336-708, South Korea
}

\begin{abstract}
The geographic distribution of koi herpesvirus (KHV) has recently been analyzed by polymerase chain reaction ( $\mathrm{PCR}$, based on the alleles of 3 domains) and sequence analysis using 3 regions of KHV genomic DNA (SphI-5, 9/5, and the thymidine kinase gene). In this study, samples from 6 carp showing symptoms of KHV infection in 2008 were examined for the presence of KHV by using PCR and cell culture isolation methods. KHV was detected in 2 (Pyeongtaek and Buan) of the samples. Sequence analysis revealed that the genotype of the KHV PT-08 isolate was Asia genotype variant 1 (A1), and the genotype of the KHV BA-08 isolate was European genotype variant 4 (E4). In addition, PCR patterns and sequence analysis based on the alleles of 3 domains of an alternate KHV classification system confirmed that the genotype of the KHV PT-08 isolate was CyHV3-J, and the genotype of the KHV BA-08 isolate was CyHV3-third genotype. To our knowledge, this is the first study to demonstrate the presence of 2 genotypes of KHV (genotype A1/CyHV3-J; genotype E4/CyHV3-third genotype) in South Korea.
\end{abstract}

KEY WORDS: Koi herpesvirus · Genotype $\cdot$ Sequencing analysis $\cdot$ Korea

\section{INTRODUCTION}

Koi herpesvirus (KHV) is a viral pathogen responsible for mass mortality among cultured cyprinids (Hedrick et al. 2000). Currently, KHV disease (KHVD) is included on the list of contagious diseases reportable to the World Organization of Animal Health (Office International des Epizooties, OIE 2009) because of its potentially harmful effects on the aquaculture industry (www.oie. int/fileadmin/Home/eng/Health_standards/aahm/ 2010/2.3.06_KHVD.pdf). KHV was first isolated from cultured fish in Israel and the US in 1998 (Hedrick et al. 2000). Since that time, KHV has been detected in Germany (Neukirch \& Kunz 2001) and again in Israel (Perelberg et al. 2003, Ronen et al. 2003), and more recently in South Africa and the European Union countries (Haenen et al. 2004), Indonesia (Yuasa 2004, Sunarto et al.
2011), Japan (Sano et al. 2004), and Southeast Asian countries (Kurita et al. 2009).

The diagnostic methods for KHV disease have been reported previously (OIE 2009) and rely on antibody-based virus detection, DNA probe in situ hybridization, antibody detection, virus isolation in cell culture, polymerase chain reaction (PCR), and sequencing analysis. The OIE (2009) recommends that PCR and nucleotide sequence analysis of the PCR products are used to confirm the identity of KHV. The genetic relationship between KHVs detected in Europe and Asia has recently been analyzed by PCR and sequencing using 3 regions of KHV genomic DNA: SphI-5, 9/5, and the thymidine kinase gene (Kurita et al. 2009). In addition, another genetic relationship system for KHV genotypes based on the alleles of 3 domains, 2 within Marker I (using a primer set between open reading frame [ORF] 29 and ORF 31) and 1 within Marker II (target- 
ing upstream and within the ORF133 region), has been proposed (Bigarré et al. 2009, Sunarto et al. 2011).

Herpes-like viral infections have been described in cultured common carp Cyprinus carpio in Korea in 1998, although the causative agent was not identified (Oh et al. 2001, Choi et al. 2004). The causative agent was finally identified as KHV in Korea in 1998 by using an in situ hybridization method (Lee et al. 2012). In 2010, a case of early-stage KHV infection was reported in a koi (C. carpio koi) broodstock commercial farm in South Korea (Gomez et al. 2011), and the infection was subsequently monitored in 2010 (Cho et al. 2011).

In the present study, samples from 6 carp that showed clinical signs of KHV infection in 2008 were examined for the presence of KHV using PCR and cell culture isolation methods. KHV was detected in 2 of the 6 samples, and the genotypes of these $2 \mathrm{KHV}$ isolates were subsequently determined using PCR and nucleotide sequencing analysis.

\section{MATERIALS AND METHODS}

\section{Fish}

Diseased carp were collected in 2008 from 6 carp farms located in Pyeongtaek, Buan, Jeongeup, and Jeonju in South Korea. The common findings exhibited by the fish were severe gill lesions, which manifested as gill mottling with white patches. The gills were collected in $50 \mathrm{ml}$ Corning tubes and were stored at $-80^{\circ} \mathrm{C}$ until use.

\section{Detection of KHV DNA}

DNA was extracted from the gills using a DNeasy Tissue Extraction Kit (Qiagen) according to the manufacturer's instructions. The extracted samples were stored at $-80^{\circ} \mathrm{C}$ until they were used for PCR analysis for KHV DNA. The Bercovier TK primer set (forward, 5'-GGG TTA CCT GTA CGA G-3'; reverse, 5'-CAC CCA GTA GAT TAT GC-3') was used to amplify the KHV gene (OIE 2009) in a $25 \mu \mathrm{l}$ PCR mixture containing 10 pmol of each primer, $0.2 \mathrm{mM} \mathrm{dNTP}, 2 \mathrm{mM} \mathrm{MgCl}_{2}$, and $1.25 \mathrm{U}$ Ex-Taq DNA polymerase (TaKaRa). The PCR protocol was as follows: initial 5 min step at $94^{\circ} \mathrm{C}_{i} 40$ cycles of 1 $\min$ at $94^{\circ} \mathrm{C}, 1 \mathrm{~min}$ at $55^{\circ} \mathrm{C}, 1 \mathrm{~min}$ at $72^{\circ} \mathrm{C}$; and a final extension step of $10 \mathrm{~min}$ at $72^{\circ} \mathrm{C}$. The amplified DNA was separated on $1.5 \%$ agarose gels contain- ing ethidium bromide $\left(0.5 \mu \mathrm{g} \mathrm{ml}^{-1}\right.$; Sigma), and the bands were visualized using a Gel Doc UV transilluminator (Bio-Rad Laboratories).

\section{Virus isolation}

The Koi fin-1 (KF-1) cell line was cultured using L15 (Gibco Life Technologies) supplemented with $10 \%$ fetal bovine serum, $100 \mathrm{IU} \mathrm{ml}^{-1}$ penicillin $\mathrm{G}$, and $100 \mu \mathrm{g} \mathrm{ml} \mathrm{m}^{-1}$ streptomycin sulfate. The cells were grown at $20^{\circ} \mathrm{C}$ for $2 \mathrm{wk}$ and then seeded in 24 -well tissue culture plates. The fish gills used in PCR analysis were homogenized with 9 volumes of Hank's balanced salt solution (HBSS; Invitrogen) containing $10 \times$ concentration of antibiotic-antimycotic solution (Gibco Life Technologies) and then centrifuged at $2000 \times g\left(10 \mathrm{~min}\right.$ at $\left.4^{\circ} \mathrm{C}\right)$. The supernatants were filtered using a filter with a pore size of $0.45 \mu \mathrm{m}$ (Millipore). The fluids were inoculated onto the KF-1 cells seeded in 24-well tissue culture plates, and the plates were then incubated at $20^{\circ} \mathrm{C}$ for observation of cytopathic effects (CPEs).

\section{PCR for genotype analysis}

The 3 genomic regions (SphI-5, 9/5, and the thymidine kinase [TK] gene) and the variable regions of KHV (between ORF29 and ORF31, Marker I; ORF133, Marker II) were amplified according to the methods described by Kurita et al. (2009) and Bigarré et al. (2009), respectively. DNA was amplified using SphI-5, 9/5, and TK gene primer sets in $25 \mu \mathrm{l}$ PCR mixtures containing $10 \mathrm{pmol}$ of each primer, $0.2 \mathrm{mM} \mathrm{dNTP}, 2 \mathrm{mM} \mathrm{MgCl}_{2}$, and $1.25 \mathrm{U}$ Ex-Taq DNA polymerase. The common PCR procedure included an initial denaturation step at $94^{\circ} \mathrm{C}$ for $30 \mathrm{~s} ; 35$ cycles of denaturation at $94^{\circ} \mathrm{C}$ for $30 \mathrm{~s}$, annealing at $58^{\circ} \mathrm{C}$ for $30 \mathrm{~s}$, and extension at $72^{\circ} \mathrm{C}$ for $1 \mathrm{~min}$; and a final extension step lasting $7 \mathrm{~min}$ at $72^{\circ} \mathrm{C}$. DNA was also amplified using Marker I or Marker II primer sets in $25 \mu \mathrm{l}$ PCR mixtures containing 10 pmol of each primer, $0.2 \mathrm{mM}$ dNTP, $2 \mathrm{mM}$ $\mathrm{MgCl}_{2}$, and $1.25 \mathrm{U}$ Ex-Taq DNA polymerase. The common PCR procedure included an initial denaturation at $95^{\circ} \mathrm{C}$ for $5 \mathrm{~min}$; 40 cycles of denaturation at $95^{\circ} \mathrm{C}$ for $30 \mathrm{~s}$, annealing at $60^{\circ} \mathrm{C}$ for $30 \mathrm{~s}$, and extension at $72^{\circ} \mathrm{C}$ for $20 \mathrm{~s}$; and a final extension step lasting $5 \mathrm{~min}$ at $72^{\circ} \mathrm{C}$. Amplified DNA was separated on $1.5 \%$ agarose gels containing $0.5 \mu \mathrm{g} \mathrm{m} \mathrm{m}^{-1}$ ethidium bromide (Sigma), and the bands were visualized using a Gel Doc UV trans-illuminator. 


\section{Cloning and nucleotide sequence analysis}

Amplified PCR products were purified using a spin-column PCR purification kit (Promega) and cloned into the pGEM-T Easy vector. Plasmid DNA from the recombinant clones was extracted using a plasmid DNA extraction kit (Qiagen), and positive clones were selected using PCR, as described above. Inserts were sequenced using an ABI377 sequencer (Applied Biosystems) with T7 and SP6 primers. The resulting sequences were compared with the BLAST database (National Center for Biotechnology Information).

\section{RESULTS}

\section{Gene detection and isolation of KHV}

The KHV TK gene was detected in 2 (from Pyeongtaek and Buan samples) of the 6 carp that showed clinical signs of KHV infection in 2008, and by CPE in the KF-1 cell line (data not shown). The 2 isolates from Pyeongtaek and Buan were named PT-08 and BA-08, respectively. The locations from which the samples were obtained and characteristics of the 2 isolates are provided in Fig. 1 and Table 1.

\section{Gene sequence analysis of KHV genes (9/5 region, SphI-5, and enlarged TK) in the PT-08 and BA-08 isolates}

The DNA sequences of the KHV PT-08 isolate from koi revealed that the nucleotides (nts) at positions 184-187 and 212-218 of the 9/5 region were TTT T and AAA AAA, respectively. When the $S p h \mathrm{I}-5$ region was examined, C was detected at nt 209, while AAC was not observed at nts 586-588. In the enlarged TK gene region, $\mathrm{C}, \mathrm{A}, \mathrm{AA}, \mathrm{TTT}$ TTT T, CTT TAA AAA AAA, and AGA TAT T were detected at nts 94, 778, 849/850, 877-885, 945-956, and 961-967, respectively, while AT and CA were not observed at nts 813-814 and 957-958, respectively (Table 2). These results indicate that the KHV PT-08 isolate belongs to Asia genotype variant 1 (A1) according to the method described by Kurita et al. (2009).

The DNA sequences of the KHV BA-08 isolate from common carp revealed that nts $184-187$ of $9 / 5$ were TTT $\mathrm{T}$ and nts 212-218 were AAA AAA A (Table 2). C

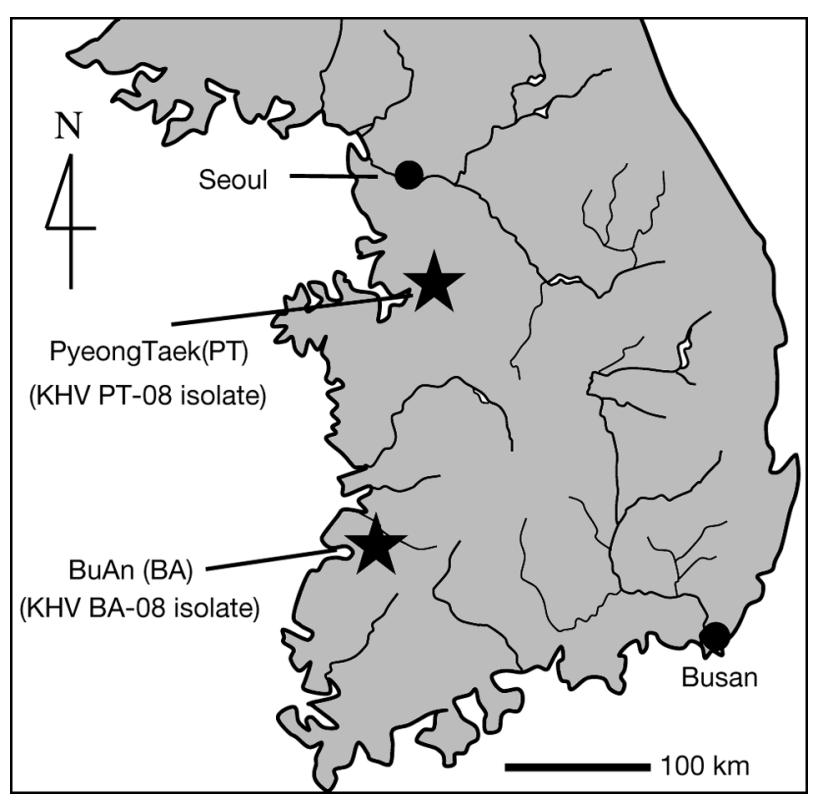

Fig. 1. Locations in Korea from which KHV-positive samples were obtained for this study

was detected at nt 209 in the $S p h I-5$ region, whereas AAC was detected at nts 586-588 (Table 2). In addition, the sequences at nts $94,778,813-814,849 / 850$, 877-885, 945-956, 957-958, and 961-967 in the enlarged TK gene region were $\mathrm{C}, \mathrm{G}, \mathrm{AT}, \mathrm{AA}, \mathrm{TTT}$ TTT TTT, CTT TAA AAA AAA, CA, and AGA TAT T, respectively (Table 2). These results indicate that the KHV BA-08 isolate belongs to European genotype variant (E4) according to the method described by Kurita et al. (2009).

\section{Analysis of KHV genes based on the alleles of 3 domains in the PT-08 and BA-08 isolates}

The 168 bp (Fig. 2, lane 1) and 153 bp (Fig. 2, lane 2) PCR products were amplified using the Marker I PCR primer set with DNA from the PT-08 and BA-08 isolates, respectively. The DNA sequences of the Marker I PCR product from the KHV PT-08 isolate revealed the sequences GCA GCC TCA ACC CCG GC and GAG TCG TCC ACG ATG

Table 1. Origins of $2 \mathrm{KHV}$ isolates collected from fish farms in South Korea

\begin{tabular}{|lccc|}
\hline Isolate & Sampling location & Material & Date \\
\hline KHV PT-08 & Pyeongtaek (PT) & Koi (gills) & 15 June 2008 \\
KHV BA-08 & Buan (BA) & Common carp (gills) & 08 June 2008 \\
\hline
\end{tabular}




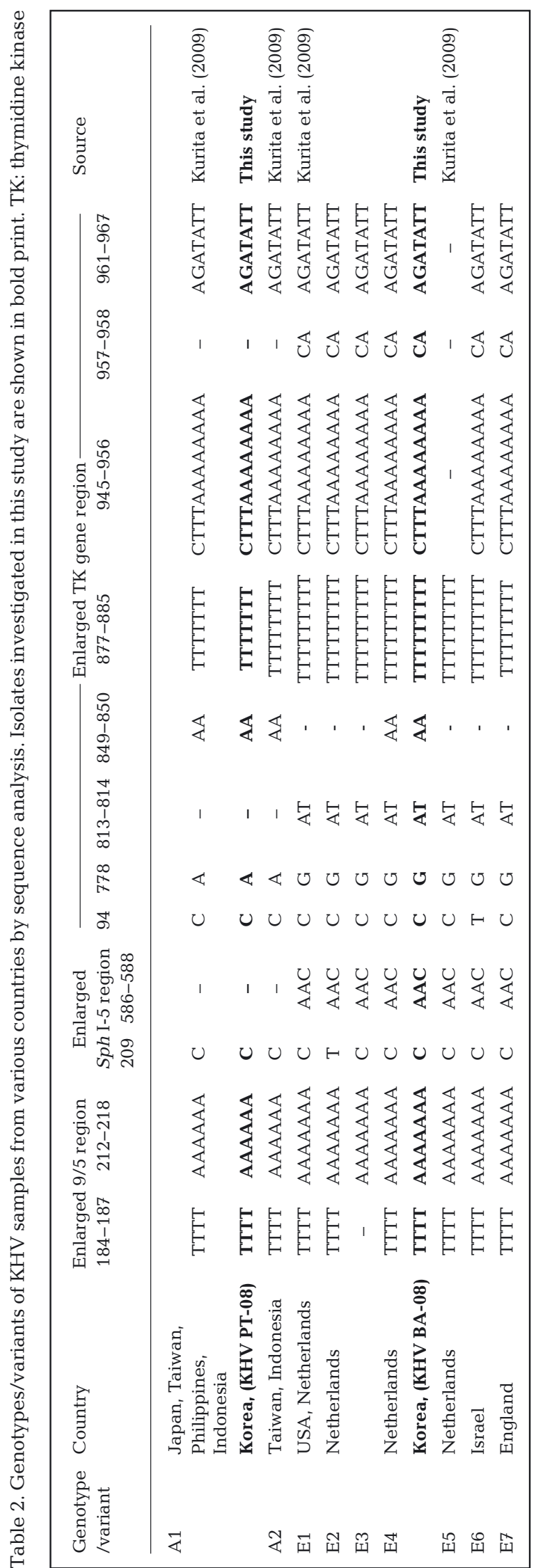

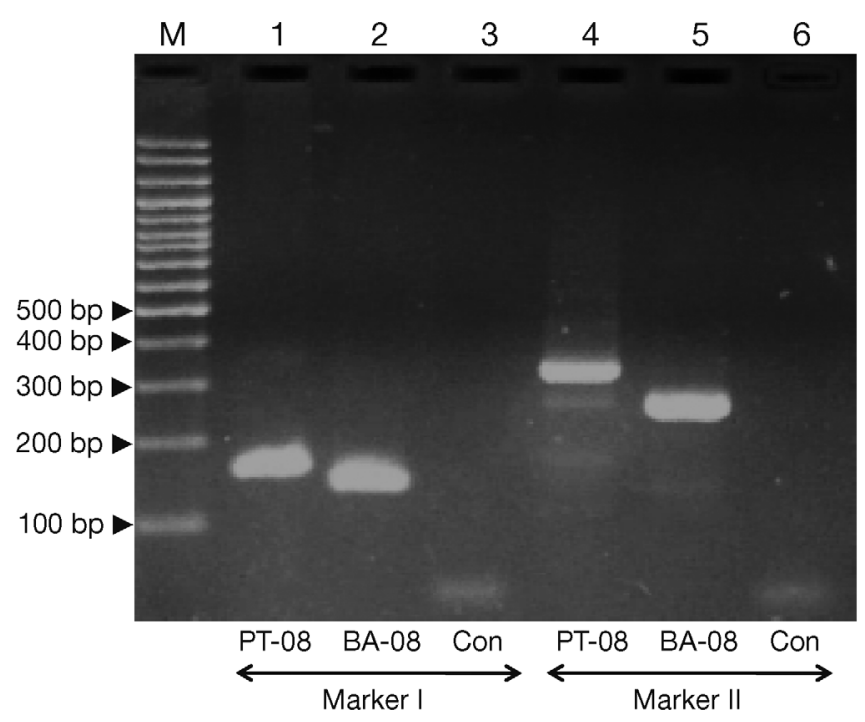

Fig. 2. Agarose gel electrophoresis of PCR products for the Marker I primer set (lanes 1, 2, and 3) and Marker II primer set (lanes 4, 5, and 6). Lanes 1 and 4: Isolate PT-08; Lanes 2 and 5: Isolate BA-08; Lanes 3 and 6: DNA sample from healthy carp as controls (con)

GTG ACA CC at nts 16-32 and positions 82-104, respectively (Fig. 3). However, the DNA sequences of Marker I from the KHV BA-08 isolate revealed nts at positions 82-104, while the nts were not observed at positions 16-32 (Fig. 3).

In addition, the PCR product of full-length $352 \mathrm{bp}$ (Fig. 2, lane 4) DNA of the PT-08 isolate was observed in the Marker II region, while a PCR product of 278 bp (Fig. 2, lane 5) containing a 74 bp deletion was observed in the BA-08 isolate.

Bigarré et al. (2009) used (+) and (-) symbols to indicate the presence and absence of each of the 3 variable domains, respectively. Thus, the genotype allele of PT-08 isolate was confirmed as $\mathrm{I}^{++} \mathrm{II}^{+}$, because 168 bp (Fig. 2, lane 1) and 352 bp (Fig. 2, lane 4) were detected by PCR using Marker I and II primer sets, respectively. Additionally, the genotype allele of isolate BA-08 was confirmed as $\mathrm{I}^{-+} \mathrm{II}^{-}$, because $153 \mathrm{bp}$ (Fig. 2, lane 2) and 278 bp (Fig. 2, lane 5) were detected by PCR using Marker I and II primer sets, respectively. Thus, it was confirmed that the PCR patterns of PT-08 and BA-08 isolates are $\mathrm{I}^{++} \mathrm{II}^{+}$and $\mathrm{I}^{-+} \mathrm{II}^{-}$, respectively (Fig. 3).

\section{DISCUSSION}

Recently, Lee et al. (2012) reported that the mass mortality of carp observed in 1998 was associated with KHV infection, and the virus was introduced 
into carp farms in South Korea in 1998 or earlier. However, the identification of KHV was not reported until 2010 in South Korea (Cho et al. 2011). In the present study, samples from 6 carp showing gross lesions consistent with KHV infection in 2008 were examined by PCR using a KHV TK primer set and virus isolation. KHV was detected by PCR in 2 samples (PT-08 and BA-08), and by CPE in the KF-1 cell line (data not shown). These results confirmed the presence of KHV in the carp fisheries of South Korea in 2008 (Fig. 1).

For genotype analysis, the DNA sequences of the KHV PT-08 isolate from koi are displayed in Table 2 where they are compared with other known isolates. The total nucleotide sequences of the SphI-5, 9/5, and TK genes of the KHV PT-08 isolate revealed $100 \%$ identity with KHV genes (GenBank accession numbers: AB375381, AB375384, and AB375390, respectively). Thus, the genotype of the KHV PT-08 isolate in this study was found to be Asia genotype variant 1 (A1), thereby confirming the presence of the Asian type of KHV in South Korea. Additionally, the allele of PT-08 isolate was also confirmed as $\mathrm{I}^{++}$ $\mathrm{II}^{+}$, specifically, the CyHV3-J genotype in Asia. The geographical distribution of the A1 genotype has previously been reported by Kurita et al. (2009) to include Japan, Taiwan, and Indonesia. In fact, all koi were imported to South Korea from Japan until 2008; therefore, the KHV PT-08 strain may have come from Japan, although evidence for this hypothesis is circumstantial.

Despite the geographical location in Asia, the genotype of the KHV BA-08 isolate from common carp in South Korea was revealed to be a European genotype variant (E4), according to the method described by Kurita et al. (2009). The total nucleotide sequences of the KHV BA-08 SphI-5, 9/5, and TK genes revealed $100 \%$ identity with KHV genes (GenBank accession numbers AB375379, AB375382, and AB375387, respectively). In addition, the PCR pattern of the BA-08 isolate was confirmed as $\mathrm{I}^{-+} \mathrm{II}^{-}$. This result indicates that the isolate is related to another genotype distinct from the CyHV3-I, U, and J genotypes. It was reported that KHV strains in the Netherlands included several genotypes (E1-E5) and several alleles $\left(\mathrm{I}^{--} \mathrm{II}^{-}\right.$, CyHV3-U/I genotype; $\mathrm{I}^{++} \mathrm{II}^{+}$, CyHV3-J genotype; $\mathrm{I}^{-+} \mathrm{II}^{-}$, third genotype; Bigarré et al. 2009, Kurita et al. 2009). Thus, it was confirmed that our BA-08 isolate was an identical genotype to one of the Netherland isolates (E4 genotype variant and third genotype allele). Until 2008, common carp were not imported from European countries including the Netherlands; rather, most common carp were 
imported from China. However, there is no evidence for KHV transfer from China, so the virus may have been introduced by fish from a third country or fish purchased by travelers. KHV inspection has been conducted internationally since 2004 (Haenen et al. 2004), and KHV has been listed by the OIE as a reportable disease since 2006 (Taylor et al. 2010). Therefore, the spread of the disease associated with this virus was not internationally controlled before 2004.

In South Korea, KHV quarantine for import or export of carp was conducted under the purview of the Quality Control of Fishery Products Act until 21 December 2008. In the case of export, carp were inspected for KHV only at the request of recipient nations. Since 22 December 2008, the Aquatic Animal Diseases Control Act has been enacted and enforced in South Korea, applicable to all fish-related infectious diseases listed by the OIE. The South Korean government conducts disease surveillance and carries out preventive activities in affected areas in South Korea under the purview of this Act. Specifically, carp should be exported after biannual monitoring and confirmed to be in a disease-free state (Cho et al. 2011). Therefore, enhanced surveillance and control measures are expected to have a positive effect in controlling infectious disease, including $\mathrm{KHV}$, in South Korea.

Acknowledgements. The diseased carp were provided by J. J. Han (Gyeonggi Province Freshwater Fisheries Researches Institute, Yangpyeong-gun, Korea), while the KF-1 cell line originated in the laboratory of R. Hedrick (School of Veterinary Medicine, University of California, Davis, USA) and was then kindly provided to us by M. Yoshimizu (Faculty of Fisheries Sciences, Hokkaido University, Hakodate, Japan). This research was supported by the Basic Science Research Program through the National Research Foundation of Korea (NRF) funded by the Ministry of Education, Science, and Technology (2011-0013382).

\section{LITERATURE CITED}

Bigarré L, Baud M, Cabon J, Antychowicz J and others (2009) Differentiation between Cyprinid herpesvirus type-3 lineages using duplex PCR. J Virol Methods 158: $51-57$

Editorial responsibility: Mark Crane, Geelong, Victoria, Australia
Cho MY, Park SY, Won KM, Han HJ, Lee SJ, Cho YA, Kim JW (2011) Detection of fish pathogens in cultured juveniles for stock enhancement in 2010. J Fish Pathol 24: 121-129

Choi DL, Sohn SG, Bang JD, Do JW, Park MS (2004) Ultrastructural identification of a herpes-like virus infection in common carp Cyprinus carpio in Korea. Dis Aquat Org 61:165-168

> Gomez DK, Joh SJ, Jang H, Shin SP and others (2011) Detection of koi herpesvirus (KHV) from koi (Cyprinus carpio koi) broodstock in South Korea. Aquaculture 311:42-47

Haenen OLM, Way K, Bergmann SM, Areil E (2004) The emergence of koi herpesvirus and its significance to European aquaculture. Bull Eur Assoc Fish Pathol 24: 293-307

Hedrick RP, Gilad O, Yun S, Spangenberg JV and others (2000) A herpesvirus associated with mass mortality of juvenile and adult koi, a strain of a common carp. J Aquat Anim Health 12:44-57

Kurita J, Yuasa K, Ito T, Sano M and others (2009) Molecular epidemiology of koi herpesvirus. Fish Pathol 44:59-66

> Lee NS, Jung SH, Park JW, Do JW (2012) In situ hybridization detection of koi herpesvirus in paraffin embedded tissues of common carp Cyprinus carpio collected in 1998 in Korea. Fish Pathol 47:100-103

Neukirch M, Kunz U (2001) Isolation and preliminary characterization of several viruses from koi (Cyprinus carpio) suffering gill necrosis and mortality. Bull Eur Assoc Fish Pathol 21:125-135

Oh MJ, Jung SJ, Choi TJ, Kim HR and others (2001) A viral disease occurring in cultured carp Cyprinus carpio in Korea. Fish Pathol 36:147-151

OIE (Office International des Epizooties) (2009) Manual of diagnostic tests for aquatic animal diseases, 6th edn. OIE, Paris

Perelberg A, Smirnov M, Hutran M, Diamant A, Bejerano Y, Kotler M (2003) Epidemiological description of a new viral disease affecting cultured Cyprinus carpio in Israel. Isr J Aquacult Bamidgeh 55:5-12

> Ronen A, Perelberg A, Abramowitz J, Hutoran M and others (2003) Efficient vaccine against the virus causing a lethal disease in cultured Cyprinus carpio. Vaccine 21: 4677-4684

Sano M, Ito T, Kurita J, Yanai T, Watanabe N, Miwa S, Iida $\mathrm{T}$ (2004) First detection of koi herpesvirus in cultured common carp Cyprinus carpio in Japan. Fish Pathol 39: 165-167

> Sunarto A, McColl KA, Crane MSJ, Sumiati T, Hyatt AD, Barnes AC, Walker PJ (2011) Isolation and characterization of koi herpesvirus (KHV) from Indonesia: identification of a new genetic lineage. J Fish Dis 34:87-101

Taylor NGH, Dixon PF, Jeffery KR, Peeler EJ, Denham KL, Way K (2010) Koi herpesvirus: distribution and prospects for control in England and Wales. J Fish Dis 33:221-230

Yuasa K (2004) Koi herpesvirus (KHV) disease occurred in Indonesia. Ornam Fish Med 4:13-16 (in Japanese)

Submitted: October 29, 2012; Accepted: February 18, 2013 Proofs received from author(s): June 2, 2013 